\title{
Implementation of Cultural Education In Elementary School
}

\author{
I Ketut Sudarsana ${ }^{1}$, I Wayan Suyanta ${ }^{2}$, I Gusti Ayu Ratna Pramesti Dasih ${ }^{3}$, Erwin Putera \\ Permana $^{4}$, Dian Rianita ${ }^{5}$, Erwinsyah Satria ${ }^{6}$, Abdul Rahman Suleman ${ }^{7}$, Akbar Iskandar ${ }^{8}$ \\ \{liketutsudarsana@uhnsugriwa.ac.id\} \\ ${ }^{1,2,3}$ Universitas Hindu Negeri I Gusti Bagus Sugriwa Denpasar, Bali, Indonesia, ${ }^{4}$ Universitas Nusantara \\ PGRI Kediri, Indonesia, ${ }^{5}$ Faculty of Administration, Universitas Lancang Kuning, Pekanbaru, \\ Indonesia, ${ }^{6}$ Elementary School Teacher Education Program, Faculty of Teacher Training and \\ Education, Universitas Bung Hatta, Padang, Indonesia, ${ }^{7}$ Faculty of Economics, Universitas Graha \\ Nusantara Padangsidimpuan, Indonesia, ${ }^{8}$ Informatics Engineering, STMIK AKBA, Makassar, Indonesia
}

\begin{abstract}
Ethnic Education is one of true character Indonesian people that must be owned by every citizen. This effort starts from the sector of education as a fondation to the next generation. Especially for the Elementary School level. Character education includes morality that is very useful for a child when they has become an adult. The goals of Cultural education is to build the better character whi exudes noble qualities. The Implementation of character education is carried through direct learning, extracurricular practices, and role of Hindu teachers whi build a better manners. That can be example for students, and contstraint for each students who have different character, the effort can be through a subtle approach.
\end{abstract}

Keywords: Cultural Education; Elementary School

\section{Introduction}

Quality Human Resources (HR) is very needed to deal with rapid changes of globalization era. To realize the quantity of human resources is to responsibility of education sector, especially in preparing competent, strong, creative, independent, and professional students. Haedar Nashir explained that in reality, Indonesian people (especially children) are currently not paying attention to morals as reflected in the behavior of not respecting human values, such as teenage brawls, lack of respect for parents, disobedience to family norms, and undisciplined life [1]. Especially in the era of globalization, human beings tend to behave violenty, fast, accelerate in solving something and instant culture. Humans are forced to live like robots, always in high competition (conflict) with each others, life is like a wheel spinning fast, which makes humans leave universal norms, use the concept of justifying all means, selfishness, and not having good norms, not appreciating, caring, loving, and loving everything.

The importance of education or coaching moral behaviour for students, with moral guidance is universal, students are expected to be able to respect the lives of others reflected in their behaviour and self actualization, since elementary school, until later becoming a better citizen. With the provision of moral and ethical education for students, we hope that it can change the behaviour of children, so that students who become adults are more responsible, 
respect each other and are able to faces the challenges of rapidly changing era. This is where the importance of moral and ethical values for students who function as a medium for human transformation to be better than before, have superiority and intelligence in various fields, namely emotional intelligence, social intelligence, kinesthetic intelligence, logical intelligence, musical, linguistik. The role of parents (teachers) is limited to giving the best things in according the spirit of facing an era. So later the students is like an arrow who escapes from its bow, overcome its own problems, but has good and noble moral superiority [2].

According to Edi Sedyawati said that the notion of character was translated from the notion of morality, which contained several meanings including customs, manners and behavior [3]. Moral and ethical education in shcools is carried out by teachers with the aim of forming students who have noble morality, nobility, so that later they will be useful for the nation and state. Moral education programs are integrated into all existing lessons, so as to produce good citizens [4].

Teaching and learning interaction, as a teacher and strives, maximally using various skills and abilities, so that the child can achieve the expected goals. Therefore the teacher creates a good situations so that students can learn well, because in fact, the teaching and learning process has not been said to end if students have not been end if students havent been able to learn and experience behavioral changes, because behavior changes are learning outcomes. Behavioral changes are defined as changes that cover three aspects of human behavior, cognitive aspects, psychomotor aspects, and affective aspects.

\section{Method}

This research uses qualitative research with deductive - inductive method and its reporting is descriptive and narrative. Data collection was carried out through in-depth interviews with several key informants. After the data has been collected, it is analyzed using the following steps: (1) data reduction, (2) data display (3) drawing conclusions and (4) data verification.

\section{Result and Discussion}

\subsection{Character Education}

Education or character education, in general are both main means a formal educational institution who purpose and function are to make fundamental changes to students in particular. Because ethics education is a very appropriate, means to bring students to a fundamental change of attitude to foster good moral and ethical values, so that students are able to become responsible children.

Character education is a school teaching program that aims to develop students character by living the values and beliefs of society as a moral force in their lives through honesty, discipline , morality, and good ethics in social life. Character education is also presonality, where character education is part of the teachings of Hinduism. According to Draft [5] the notion of character in Concepts and Operational as follows : 
a. Conceptual education

1) A conscious effort to male students become fully human and noble character that is useful for society and nation.

2) All efforts to develop, improve, maintain the behavior of students so that they are able to carry out their life duties in harmony, in accordance with the applicable rules.

3) Educational efforts to form students become individuals who are virtuous with noble character through learning, habituation and practice.

b. Definition of character education

Character education is operationally defined as an effort to equip students through guidance and training during the growth and development of students for future provision, so that students have clear conscience, manners, morals and ethics by carrying out their obligations to god and all beings.

The personality will be reflected in the behavior of speech, mind and others based on religious values, the norms, and noble morals of the nation. Ethic education has a very deep meaning that is an effort or activity that leads a child to become an adult by having a noble ethic, morals in order to become a role model and can deliver the children to achieve success in the future. Ethnic education is the teachings of Hinduism has a meaning as a point of view that will be used as a reference in developing character education in accordance with the teachings of Hinduism [6] [7]. In a simple sense, ethnic education has the meaning to deliver humans or someone to the level of life that emits adult behaviour.

\subsection{Purpose and Functions of Character Education}

Everything a person does must have a goal to be achieved. Like the character education provided to students also has the following objectives and functions :

a) Encouraging the habits and behavior of students who commendable and in line with universal values, national values and religious traditions of the nations culture.

b) Embed the spirit of leadership and responsibility of studenst as the nations successor.

c) Fostering students mental and sensitivity to the surrounding situation so as not to fall into deviant behavior, both individually and socially.

d) Improve the ability to avoid despicable traits who can damage yourself, others, and the environment [8].

Characteristic education functions for students are follows :

a) Development, which is to improve good behavior for students who are embedded in the family and community environment.

b) Distribution, which is to help students who have certain talents in order to develop and benefit optimally in accordance with the national culture

c) Improvement, namely to correct students mistakes, shortcomings and weaknesses their daily behavior.

d) Prevention, namely to prevent negative behavior that is not accordance with the teachings of the nations religion and culture.

e) Cleanser, which is to cleanse yourself of liver diseases such as arrogant, selfish, jealous, envy so that students grop and develop in accordance with the teachings of the nations religion and culture.

f) Filters, namely to filter the national cultures themselves and the cultures of other nations that are not in accordance with the values of noble character. 


\section{Conclusion}

The implementation of character education in elementary schools can be taught specifically by teachers of character education and integrated with religious subject and other subject. All teachers in school have the responsibilty to carry out the character education that is integrated with the subjects held by their respective teachers.

The role of the teacher in the formation and character learning in elementary schools is the form of teachers as corrector, (able to correct the good and bad deeds of students), as an inspirator (the teacher can provide good ideas for students learning progress,) as an informator, teachers must be able to provide information with knowledge and technology as organizers). Teacger have management activities, academic activities, formulating school rules, compiling academic calendars, and so on.

As a motivator, (motivation is one aspect which is very important), as an initiator, (the originator of ideas of progress in education and teaching), as a facilitator (in character learning, the teacher plays a role in service to facilitate students in the learning process), as a mentor, (guiding students to be able to achieve and carry out their developmental tasks, so that by achieving that, he can grow and develop as an ideal human being that becoming hope of every parent and community), as demonstator (the teacher as a demonstator is the role to show the students everything that makes students better understand and understand each message delivered), as a classroom manager, (as a learning manager, the teacher plays a role in creating a learning climate that students may learn comfortably, as mediators (teachers should have knowledge of educational media in various ways).

The type, both non material and material media, as a supervisor, (the teacher should be able to help, improve and critically assess the learning process), as an evaluator (a teacher evaluator plays a role to collect data or inmormation about the success of learning that has been done. As a learning source (the role of the teacher as a source of learning is a very important role. This role is related to mastery of learning material.

\section{References}

[1] H. Nashir, "Sekuralisme Politik dan Fundamentalisme Agama: Ketegangan Kreatif Hubunan Agama dan Politik," Unisia, 2002.

[2] Habibah, Metode Pengembangan Moral Anak Pra Sekolah. Yogyakarta: UNY, 2007.

[3] E. Sedyawati, "Pariwisata dan Pengembangan Budaya," in Pariwisata Budaya Masalah dan Solusinya, 2006.

[4] T. Romi, Pentingnya Pendidikan Moral. Yogyakarta: PBS, UNY., 2007.

[5] B. Manullang, "Grand Desain Pendidikan Karakter Generasi Emas 2045," J. (Pendidikan Karakter), 2013.

[6] I. K. Sudarsana, "Optimalisasi Pemahaman Ajaran Tri Hita Karana Dalam Meningkatkan Karakter Siswa Sekolah Dasar (Perspektif Psikologi Pendidikan),” Pros. Semin. Nas. Pendidik. Dasar 2, pp. 250-256, 2017.

[7] I Ketut Sudarsana, "Pengaruh Model Pembelajaran Kooperatif Terhadap Peningkatan Mutu Hasil Belajar Siswa," J. Penjaminan Mutu, 2018.

[8] S. Adiwikarta, Peran dan Strategi Dasar Pendidikan DalamPeningkatan Sumber Daya Manusia. Seminar Nasional Tentang UpayaPengentasan Kemiskinan di Desa Terpencil. Bandung: IKIP Bandung, 1994. 